\title{
Optimization of Cable Harness Assembly Systems Based on Lean Concept Application
}

\author{
Nataša Klašnja \\ Faculty of Technical Sciences, University of Novi Sad, Novi Sad, Serbia, natasa.klasnja@gmail.com \\ Nemanja Sremčev \\ Faculty of Technical Sciences, University of Novi Sad, Novi Sad, Serbia, nextesla@uns.ac.rs \\ Djordje Vukelić \\ Faculty of Technical Sciences, University of Novi Sad, Novi Sad, Serbia, vukelic@uns.ac.rs \\ Nenad Simeunović \\ Faculty of Technical Sciences, University of Novi Sad, Novi Sad, Serbia, nsimeun@uns.ac.rs \\ Milovan Lazarević \\ Faculty of Technical Sciences, University of Novi Sad, Novi Sad, Serbia, laza@uns.ac.rs
}

Received (15.07.2018.); Revised (23.09.2018.); Accepted (27.09.2018.)

\begin{abstract}
In this writing paper an analysis of production system for assembly of cable harness from the point of the time for assembly and losses in working process has been implemented. A suggestion has been made according to a methodology for advancement in assembly system based on Lean concept. Based on this suggested methodology an optimization of numbers of working stations has been executed. The obtained results point out that efficient implementation of Lean concept in assembly process of cable harness is possible. At the end are given the appropriate conclusions and directions of future researches.
\end{abstract}

Key words: assembly, lean, cable harness

\section{INTRODUCTION}

The course of materials within a manufacturing system ought to be continuous with maximal flexibility and with adaptability of business strategies. Manufacturing system should in the shortest time period suit the demands of the buyer, minding that in that period the stagnation, the accumulation of unfinished products, etc. does not happen. This request is the imperative of every manufacturing system, no matter the size of the material and human resources and potentials. The companies which have identificated this need to adapt their business strategies to new conditions that the market and the environment dictate nowadays are the global leaders and industrial giants. System, focused on the buyer, has been created with the idea that with optimization of the process a cheaper product is available, within the shortest deadline and with the necessary quality. This system is the base of Lean manufacturing. With the implementation of this, an establishment of continuous process with continuous system identification and the removal of unnecessary occurrences within the company's business, e.g. the elimination of everything that does not represent the value is made. Within production, the product goes through series of successive operations. One of these operations is the assembly. Within the process of assembly it is necessary to provide the course where there are eliminated all the unnecessary waiting's so that the product can continuously move through the whole assembly process. The optimal assembly systems, among others, strive toward lessening engaged resources. With this, the need for intercommunity and overtime storage of the finished products, which presents a tied capital which cannot be used, is less [1-9].

In previous period, a great number of researches was referring to the implementation of the Lean concept in the assembly process. For example, Alvarez et al. [10] studied the use of value stream mapping as a tool in lean manufacturing implementation and a framework of improvement activities. They illustrated use of value stream mapping, as well as kanban and milkrun systems application on an assembly line. The results obtained show the path of improvement, measured through the lean rate and time. Johnson et al. [11] studied the internal logistics of a bus assembly plant that follows a lean assembly process dictated by takt time production. The assembly system worked according to a rigid sequential order of the assembly of different models of buses. A simulation model was developed to study assembly system. The numerical results are applicable to the selected plant only. Yi et al. [12] investigated the losses of electronic components 
throughout the surface-mounting process in electronics assembly. They generate a suitable mixture of strategies and applied DMAIC to address electronic component losses in a lean company. Sun and Zhang [13] analysed all aspects of quality control around the assembly process, store electronic resume of assembly process, and quality defect. They forecasted and optimized the matching of key parts, which significantly improve the quality of the assembly process of the enterprise performance and business performance. Arunagiri and Gnanavel Babu [14] proposed implementation of lean manufacturing systems through layout design by the conversion of existing layout of bogie assembly shop by using the Craft method to find out the best optimized layout. Interchanging of stages of different section was considered by distant matrix and total cost calculations. Various cost of all the pair wise interchanged stages ware estimated to find the best low cost interchange. Best interchanges between the two stages were considered to the development of new proposed layout in which all the non-value added activities are eliminated. Yue [15] analysed the car-seat assembly line which has several problems such as productivity shortage, long production cycle and high inventory costs. Based on leap production, article introduced how to improve the car-seat assembly line with value stream mapping analysis, Kanban pull production management and process flow analysis. Balaji Paramesh [16] directed at the efforts intended to improve the quality of cable harness manufacturing using six sigma methodologies. It includes collection of defects data, analysis of the defects data using FMEA methodology, determining the causes and taking corrective actions to eliminate the defects. Process flow chart and manufacturing lead time ware determined and lean tools such as one-piece flow and job instruction are also used. Zhang et al. [17] applied lean six sigma in an assembly process. The DMAIC procedure in six sigma and the tools in lean production ware used to analysed and improve the process. Wan Saidin et al. [18] presented the application of lean manufacturing concepts that can be used to prevent incorrect parts size at subassembly in automotive parts production. This paper investigated the sources of inputs that cause the failure and extending to the problem solution by suggesting the lean approach. Raghavan et al. [19] focus on integrating a lean framework in a high-mix-lowvolume printed circuit board assembly environment to enhance current assembly processes and facility layouts. Kanban sizes for different assembly lines ware estimated to integrate and implement a "pull-system" into the lean framework. Material movement and facility layout ware studied to minimize work-in-process travel time. Results showed that the cycle times are decreased by $40 \%$ and the number of defects decreased by 10-30 \%, depending on different assembly processes, after the lean implementation. Kanaganayagam et al. [20] focused on using lean tools such as time and motion study, kaizen events and spaghetti map to reduce waste in a large earth moving equipment assembly line. The results demonstrated that waste in an assembly can be identified and removed by studying the process and utilising simple yet powerful lean tools. Lam et al. [21] studied an electronics assembly line. The improvement alternatives would be designed and evaluated to optimize the used resources, eliminate or reduce wastes, as well as enhance the productivity. In addition, line balancing factors would be calculated and evaluated. Nguyen and Do [22] applied lean techniques in reengineering an electronics assembly line. Reengineering focused on some aspects such as reducing wastes, standardizing works, internal logistics, workplace designing and changing layout. Some positive results have been recorded on reducing nearly $40 \%$ manpower with the same daily output. Mittal and Verma [23] presented the use of lean manufacturing tools in plastic industries for air cleaner assembly cells. The current value stream map was developed by mapping all the information and material flow. All data was collected including machine cycle time, change over time, and information flow data. The map was studied and target areas for improvement were identified to reduce the waste. Usta et al. [24] proposed hierarchical clustering analysis to design the hybrid feeding system for the assembly lines. The $A B C$ methodology was utilized to compare and evaluate alternative systems. Different scenarios were created for the clustering analysis and evaluated with the companies' production managers. Rane et al. [25] developed the different models for different input variables without disturbing existing set up, for improvement of performance of assembly line by maximising the measurement of performances like cycle time, throughput, resource utilisation and reducing the cost. Lean techniques like kaizen, total productive maintenance, line balancing, low cost automation were used for different scenarios. Effect of layout, resource distribution, combination of operations, time study, and operation sequencing techniques was studied by simulation. Devi et al. [26] evaluated current state mapping and implement future state mapping in a wet grinder manufacturing system. Current state mapping was developed by observation of cycle time, change over time and non-value added activities. The objective was to minimise the non-value added activities and achieve the required takt time. The future state mapping has arrived by incorporating various improvements in the assembly line. Botti et al. [27] introduced a novel mathematical model to design lean processes in hybrid assembly lines. The aim was to provide an effective, efficient assembly line design tool that meets the lean principles and ergonomic requirements of safe assembly work. Results show that the operator's ergonomics was a key parameter of the assembly process design, as other lean manufacturing parameters, e.g. takt time, cycle time and work in progress. Debevec et al. [28] have proposed a an innovative approach through virtual production performing, with major advantage of the concept that the virtual factory (VF) does not consume any material, resources or energy - operate only with data. Real production process is not interrupted and consequently the equipment is not occupied and cannot be damaged. 
With the analysis of the previous researches it can be deducted that the researches within the field of the implementation of Lean concept in the assembly were directed to a various industrial branches, on manufacturing systems with different production programs, with different processes and assembly's strategies, etc. The common characteristic of the previous researches is the development of the methodology, which is based on increasing the correctness of the assembly, decreasing the assembly time, the reduction of the assembly costs, the unification of assembly takt, etc. The main goal of all of these is to decrease the total costs and to increase the productivity of the whole production system, as well as the increase of the quality of all the technical, functional, aesthetic, constructional and ecological characteristics of the finished product.

In contrast to previous research, the subject of this research is the implementations of the Lean concept in the assembly system of the cable harness in the automotive industry. The main goal of the research is the optimization of the working stations based on a detailed analysis of the time and losses in the work process.

\section{METHODOLOGY}

The methodology of the research is shown in the figure 1.

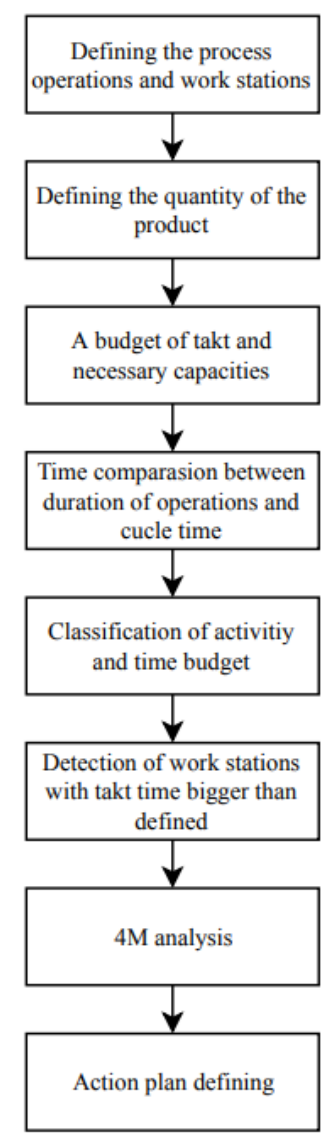

Figure 1. The Methodology

In step 1 the production system is selected and this selected group of the products are defined by the operation of the work on various work stations. The, the quantity of the annual volume production is defined. Based on this, the calculation of work takt and necessary capacities (working days, absence, the number of shifts, etc.) are performed. After this, the time tracking of the operations on every working station is done. The measured time is to be compared with the relevant work tact in order to define possible improvements. From now on, the classification of the working process is performed, in order to detect activities that add to the value i.e., does not add to the product value. Based on the classification of the activity and the measurement of the duration of every working station, the detection of work stations that have a bigger work takt than defined happens. For those work stations, in goal of eliminating NVA activities, the analysis of activities of the operators within NVA and $4 \mathrm{M}$ is conducted. Based on detailed analysis, the action plan is defined, in order to reach optimization of the production system.

\section{RESULTS}

The verification of the suggested methodology is performed in the manufacturing system for production of cable harness. It consists of several segments. The assembly segment, as the most complicated part of the system, consists of 8 operations: 1. welding, 2 . positioning, 3 . the installation of insulation, 4 . the installation of clip, 5. the installation of grommet, 6 . testing, 7. the installation of canals, and 8. packaging. The assembly line consists of 46 work stations, where are working 48 operators (figure 2.)

In the observed manufacturing system, annual production volume amounts to 313000 pieces per annum. This is taken as a parameter when the budget of work takt and necessary capacities was calculated (table 1)

Table 1. The budget of work takt

\begin{tabular}{|l|c|c|}
\hline \multicolumn{1}{|c|}{ Parameter } & Unit & Value \\
\hline Quantity & (piece/year) & 313000 \\
\hline Working days & (day/year) & 250 \\
\hline Absence & $/$ & 20 \\
\hline Number of shifts & 2 \\
\hline $\begin{array}{l}\text { Number of manufacturing } \\
\text { lines }\end{array}$ & & 6 \\
\hline Number of pieces per shift & & 113 \\
\hline $\begin{array}{l}\text { Number of working hours } \\
\text { per shift }\end{array}$ & & 8 \\
\hline Number of minutes per shift & & 48 \\
\hline Breaks & (min./day) & 30 \\
\hline Commissioning & & 10 \\
\hline Maintenance of work station & & 10 \\
\hline Team meeting & & 5 \\
\hline Total of minutes per shift & & 452 \\
\hline Total of seconds per shift & & 25500 \\
\hline Work takt & (sec./piece) & 226 \\
\hline
\end{tabular}

Even with the work tact budget of 226 seconds, as the relevant takt is adopted a bit shortened time of 192 seconds. 
The next step is to measure the duration time of the operations. This is executed with three consecutive work orders, for every work station. In figure 3 are given the measured results and their position according to relevant work takt.
From the figure 3 it is noticeable that certain work stations are overloaded, whole others demand far less time than the given cycle time. With this it is proven that some work stations have not been balanced.

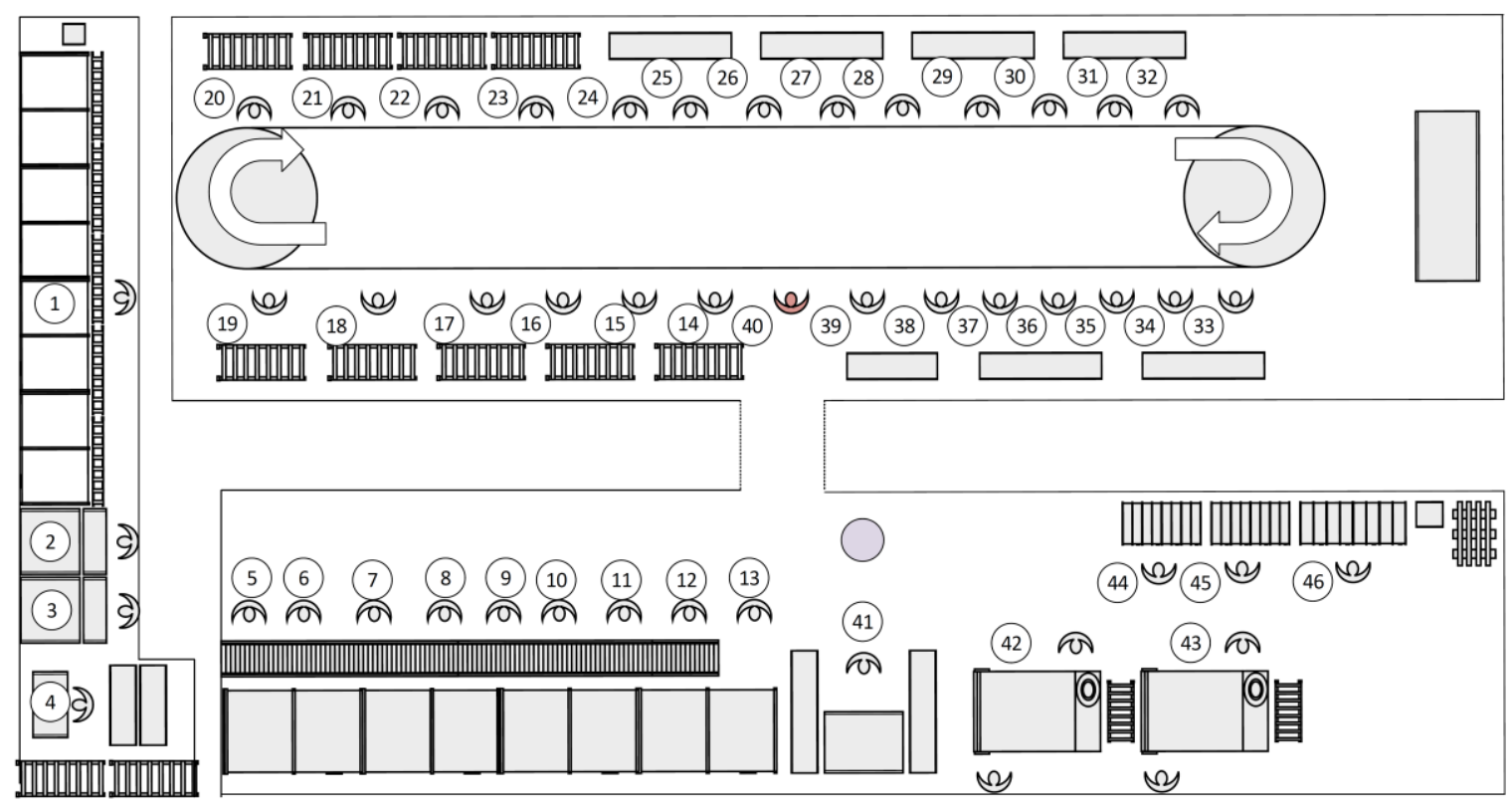

Figure 2. A layout of work stations with its operations

1 Work station - collecting wires ; 2,3 Work station - Ultrasonic welding; 4 work station - plugging 5-12 work station - pre-positioning; 13 work station - transfer; 14-23 work station - Positioning ; 24-36 work station - Banding; 37-39 work station - the installation of clip; 40 work station - Visual control; 41 work station - grommet; 42 work station clip test; 43 work station - Electro test; 44,45 work station - final assembly (the installation of canals). 46 work station - Packaging.

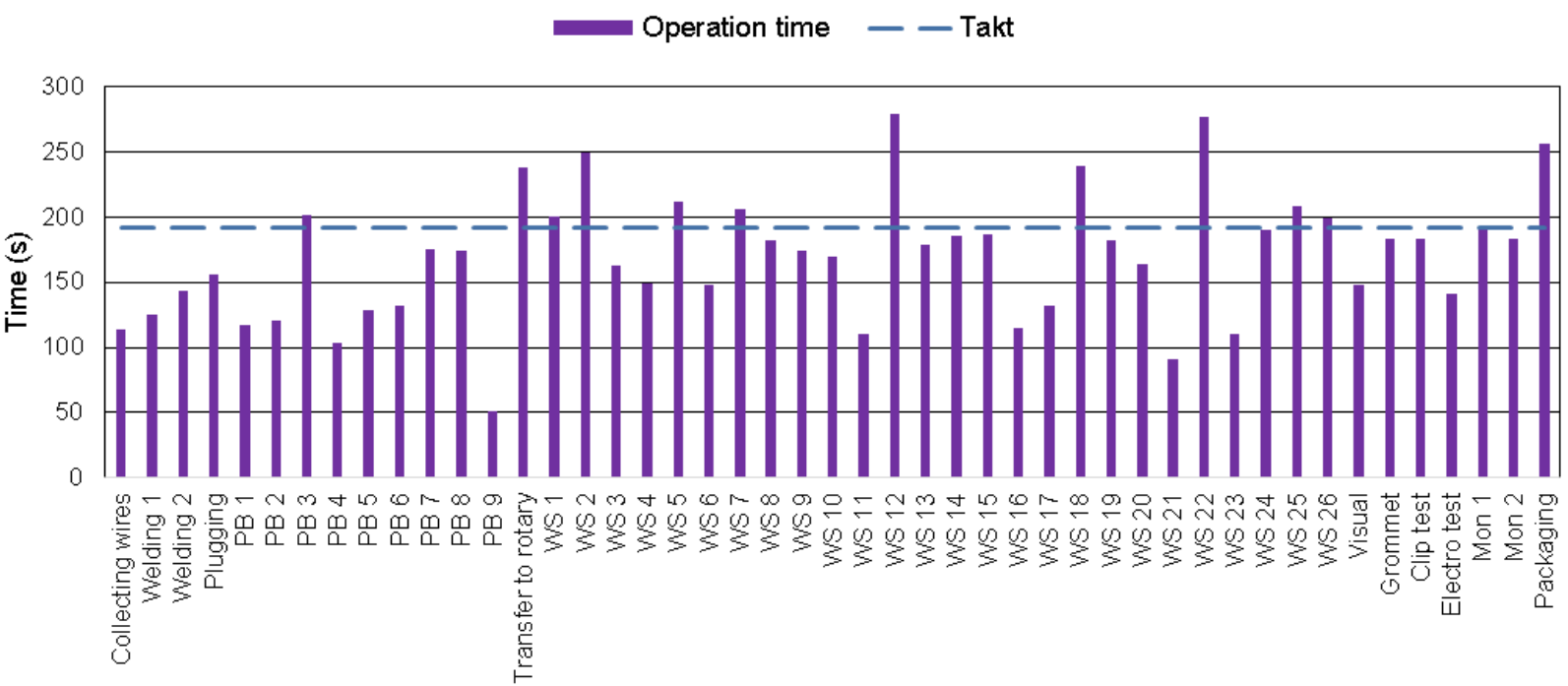

Work station

Figure 3. The time durance of operations in referring to work takt

The key to advance the process of assembly is to correctly classify the activities of the work process. VAA (Value Added Activity) is the only activity during the process that the buyer is ready to pay for. For that reason, when the classification of the working activities happens, it is necessary to understand which of the activities during the working process add to the values, which do not add to the value of the product. NVA activities are relatively easy to remove, if correctly identified.

In figure 4 are shown VAA/ RNVA and NVA activities for all work stations. In red, for better visibility, are marked NVA activities. The accent of this analysis is to enable all operations to satisfy the given work takt time of 192 seconds. As it is shown in figure 4 some of the operations overcome work takt because of the NVA 
activities. Based on the classification of activity and the measurement of the time performed for every operation, here has been detected the work stations which have bigger work takt than defined. For given work stations, in order to eliminate the NVA activities, the analysis of the activities of operators within NVA and $4 \mathrm{M}$ has been conducted.( diagram- cause-consequence). The results of this are given in the table 2 .

For the detected NVA activities, the $4 \mathrm{M}$ analysis has been done, which represents the results of a basic analysis of the influence (cause), which are under the condition of certain outcome of the reviewed occurrence. According to this, the action plan for every work station is defined (table 3.)

The performed activities, based on the action plan, have influenced the duration of operations, decreasing it to satisfy given rhythm of the process. In figure 5 is visible improvement, the operations which were over the work takt, after corrective action, are now in desired time takt. Also, the time taking to perform certain operations is significantly less from rhythm, which presents new opportunity for reviewing and balancing of the operations.

Table 2. The results of the analysis of the activities of operators within NVA

\begin{tabular}{|c|c|c|c|}
\hline \multirow{2}{*}{$\begin{array}{c}\text { Work } \\
\text { Station }\end{array}$} & $\begin{array}{c}\text { Talue } \\
\text { Added } \\
\text { Activities }\end{array}$ & $\begin{array}{c}\text { Non Value } \\
\text { Added } \\
\text { Activities }\end{array}$ & $\begin{array}{c}\text { Required } \\
\text { Non Value } \\
\text { Added } \\
\text { Activities }\end{array}$ \\
\hline PB3 & 88 & 14 & 100 \\
\hline Transfer & 66 & 95 & 77 \\
\hline WS 1 & 103 & 31 & 66 \\
\hline WS 2 & 132 & 21 & 115 \\
\hline WS 5 & 70 & 35 & 107 \\
\hline WS 7 & 101 & 79 & 12 \\
\hline WS 12 & 219 & 54 & 6 \\
\hline WS 18 & 138 & 51 & 50 \\
\hline WS 22 & 148 & 102 & 28 \\
\hline WS 25 & 148 & 102 & 28 \\
\hline WS 26 & 179 & 11 & 9 \\
\hline Packaging & 137 & 101 & 104 \\
\hline
\end{tabular}

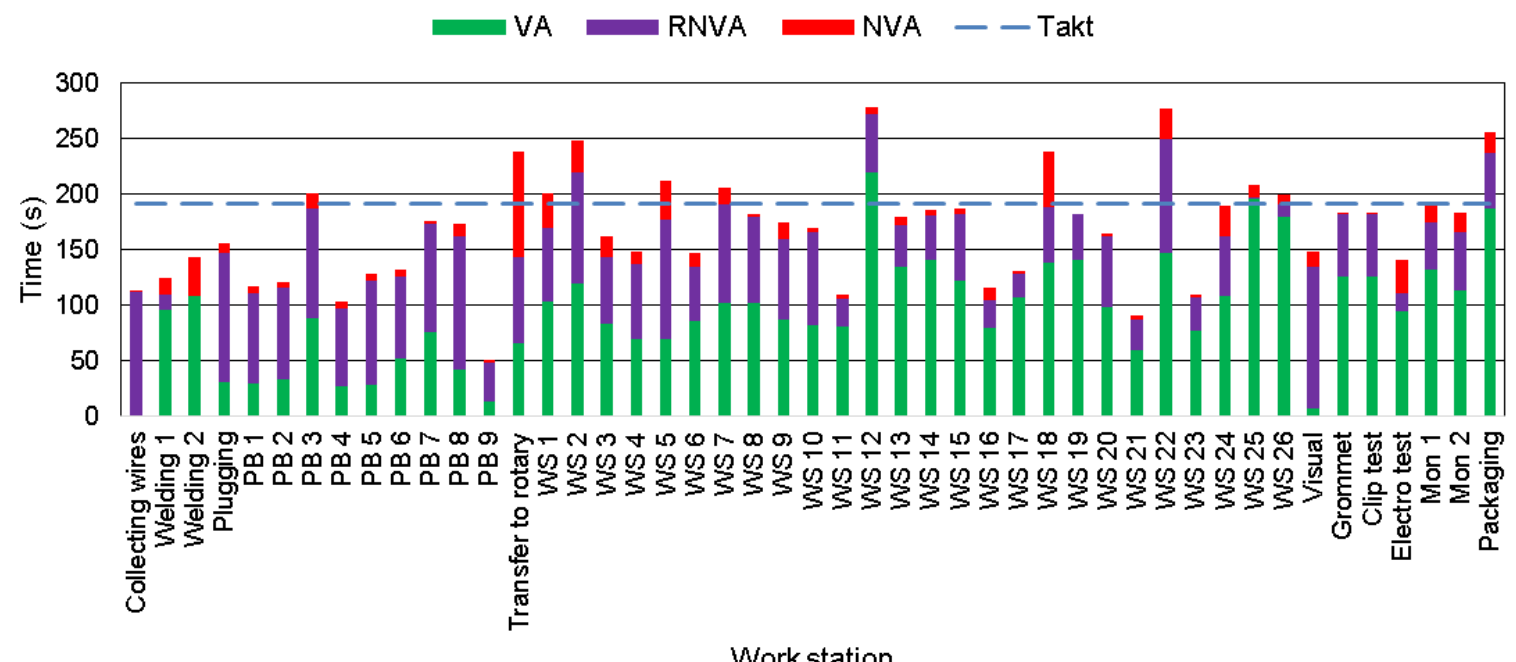

Figure 4. Duration of the work stations' operations - VA/RNVA and NVA activities

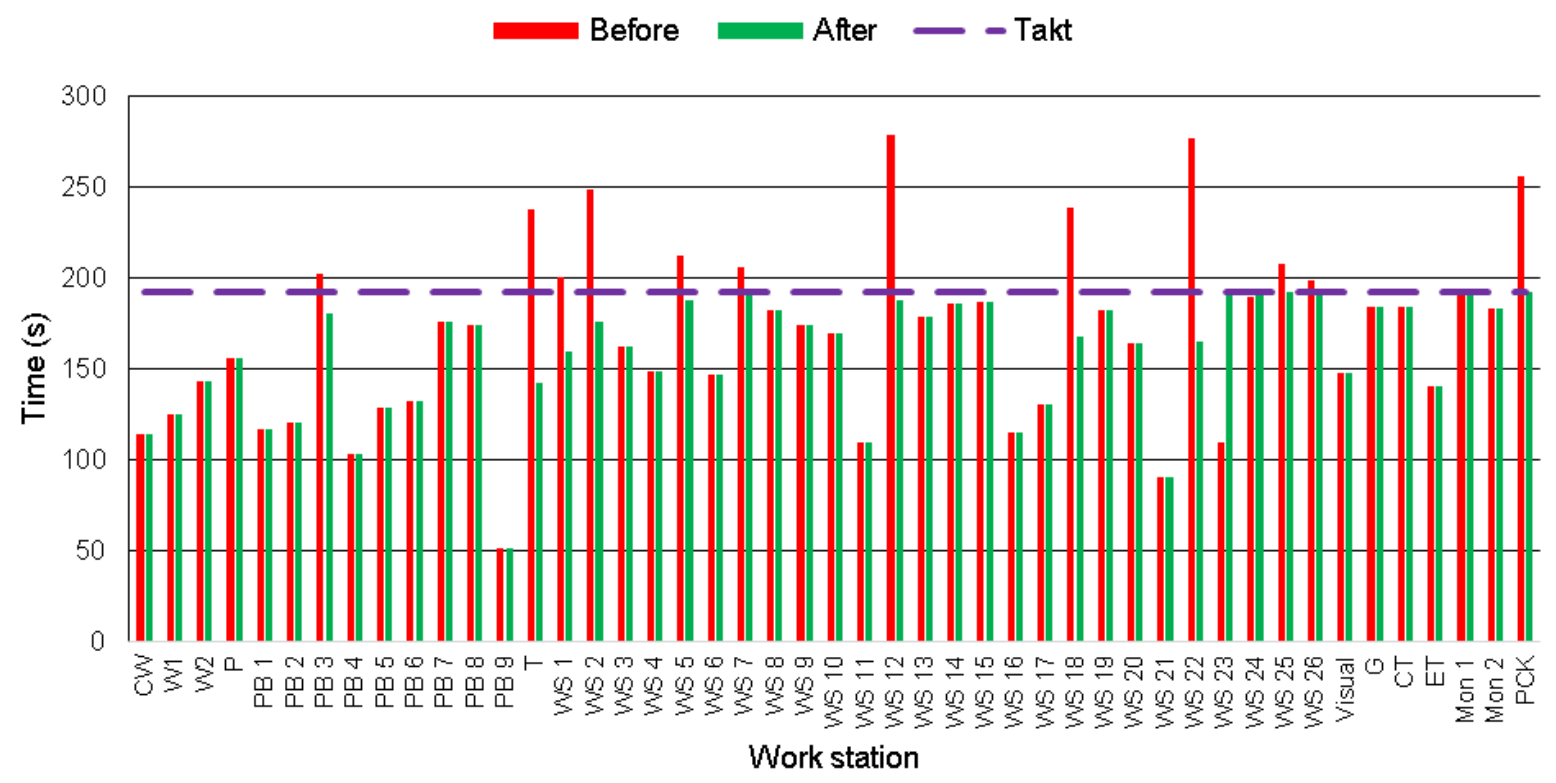

Figure 5. The results of the research, before and after improvements 
Table 3. $4 \mathrm{M}$ analysis, effects and action plan

\begin{tabular}{|c|c|c|c|c|c|c|}
\hline \multirow{2}{*}{$\begin{array}{c}\text { Work } \\
\text { station }\end{array}$} & \multicolumn{4}{|c|}{$\begin{aligned} \text { Cause } \\
\end{aligned}$} & \multirow{2}{*}{ Effect } & \multirow{2}{*}{ Action plan } \\
\hline & Man & Machine & Method & Material & & \\
\hline Plugging & $\begin{array}{l}\text { Waste time for } \\
\text { checking } \\
\text { cavities }\end{array}$ & / & / & / & $\begin{array}{l}\text { Duration of } \\
\text { operation is } \\
\text { longer }\end{array}$ & $\begin{array}{l}\text { 1. } 5 S ; 2 . \text { Teach } \\
\text { line feeder to } \\
\text { recognize } \\
\text { connectors and to } \\
\text { feed WS correctly }\end{array}$ \\
\hline PB 8 & $\begin{array}{c}\text { Not } \\
\text { experienced } \\
\text { operator, } \\
\text { collect and } \\
\text { positioning one } \\
\text { by one wire. }\end{array}$ & / & / & / & $\begin{array}{l}\text { Not able to } \\
\text { reach cycle } \\
\text { time }\end{array}$ & $\begin{array}{l}\text { 1. Train and follow } \\
\text { the skill } \\
\text { development }\end{array}$ \\
\hline PB 9 & l & / & $\begin{array}{c}\text { Process is not } \\
\text { balanced for each } \\
\text { module }\end{array}$ & / & $\begin{array}{c}\text { Duration of } \\
\text { operation is } \\
\text { sometimes too } \\
\text { short and } \\
\text { sometimes too } \\
\text { long }\end{array}$ & $\begin{array}{c}\text { Process } \\
\text { optimization }\end{array}$ \\
\hline PB 10 & $\begin{array}{c}\text { Not } \\
\text { experienced } \\
\text { operator } \\
\end{array}$ & / & / & / & $\begin{array}{l}\text { Not able to } \\
\text { reach cycle } \\
\text { time }\end{array}$ & $\begin{array}{c}\text { 1. Trainers } \\
\text { support; } 2 \text {. switch } \\
\text { operator }\end{array}$ \\
\hline WS 2 & $\begin{array}{l}\text { Struggle with } \\
\text { collection of } \\
\text { ABS }\end{array}$ & / & Overloaded WS & $\begin{array}{l}\text { Tangly } \\
\text { material on } \\
\text { reck }\end{array}$ & $\begin{array}{l}\text { Not able to } \\
\text { reach cycle } \\
\text { time, quality of } \\
\text { positioning is } \\
\text { not good }\end{array}$ & $\begin{array}{l}\text { 1. Make Line } \\
\text { feeders respect } \\
\text { the rule "MAX 50"; } \\
\text { 2. optimize WS }\end{array}$ \\
\hline WS 12 & I & / & Overloaded WS & / & $\begin{array}{l}\text { Not able to } \\
\text { reach cycle } \\
\text { time }\end{array}$ & Optimize WS \\
\hline WS 15 & / & / & / & $\begin{array}{l}\text { During } \\
\text { positioning } \\
\text { operators } \\
\text { tangled } \\
\text { wires }\end{array}$ & $\begin{array}{c}\text { Not able to } \\
\text { reach cycle } \\
\text { time. Too much } \\
\text { time for } \\
\text { adjusting wires } \\
\text { and prepare } \\
\text { branch for } \\
\text { taping }\end{array}$ & $\begin{array}{l}\text { Trainers support } \\
\text { for operators on } \\
\text { positioning. Make } \\
\text { more discipline on } \\
\text { respecting the } \\
\text { rules on } \\
\text { positioning }\end{array}$ \\
\hline WS 22 & / & / & Overloaded WS & / & $\begin{array}{l}\text { Not able to } \\
\text { reach cycle } \\
\text { time }\end{array}$ & Optimize WS \\
\hline WS 24 & / & / & / & / & $\begin{array}{l}\text { Not able to } \\
\text { reach cycle } \\
\text { time }\end{array}$ & $\begin{array}{l}\text { Switch operators; } \\
\text { More discipline } \\
\text { with line feeders- } \\
\text { material should be } \\
\text { in bins not in bags }\end{array}$ \\
\hline WS 25 & $\begin{array}{l}\text { Not fast } \\
\text { enough } \\
\text { operator }\end{array}$ & / & / & $\begin{array}{l}\text { Material is in } \\
\text { bags- } \\
\text { struggle with } \\
\text { collecting }\end{array}$ & $\begin{array}{l}\text { Not able to } \\
\text { reach cycle } \\
\text { time }\end{array}$ & $\begin{array}{l}\text { Switch operators; } \\
\text { More discipline } \\
\text { with line feeders- } \\
\text { material should be } \\
\text { in bins not in bags }\end{array}$ \\
\hline MON 2 & I & l & $\begin{array}{c}\text { Quality check } \\
\text { during operation } \\
\text { and putting dots } \\
\text { on harness }\end{array}$ & / & $\begin{array}{l}\text { Hard to reach } \\
\text { cycle time }\end{array}$ & $\begin{array}{c}\text { Find another way } \\
\text { to do quality } \\
\text { assurance of } \\
\text { product }\end{array}$ \\
\hline Packaging & $\begin{array}{l}\text { Lack of skill- } \\
\text { not enough } \\
\text { experience } \\
\text { worker }\end{array}$ & / & WS is workload & / & $\begin{array}{l}\text { Not able to } \\
\text { reach cycle } \\
\text { time }\end{array}$ & $\begin{array}{l}\text { Reorganize work } \\
\text { process (waiting } \\
\text { for approval for } \\
\text { new delivery } \\
\text { condition) } \\
\end{array}$ \\
\hline
\end{tabular}


Table 4. The cycle time for work stations

\begin{tabular}{|c|c|c|c|c|c|c|c|c|c|}
\hline $\begin{array}{c}\text { Work } \\
\text { station }\end{array}$ & Takt & $\begin{array}{c}\text { Time } \\
\mathbf{( s )}\end{array}$ & Load & $\begin{array}{c}\text { Required } \\
\text { number } \\
\text { of stations }\end{array}$ & $\begin{array}{c}\text { Work } \\
\text { station }\end{array}$ & Takt & $\begin{array}{c}\text { Time } \\
(\mathbf{s})\end{array}$ & Load & $\begin{array}{c}\text { Required } \\
\text { number } \\
\text { of stations }\end{array}$ \\
\hline CW & 192 & 114 & 0.59 & 1 & WS 11 & 192 & 110 & 0.57 & 1 \\
\hline W1 & 192 & 125 & 0.65 & 1 & WS 12 & 192 & 188 & 0.98 & 1 \\
\hline W2 & 192 & 143 & 0.74 & 1 & WS 13 & 192 & 179 & 0.93 & 1 \\
\hline P & 192 & 156 & 0.81 & 1 & WS 14 & 192 & 186 & 0.97 & 1 \\
\hline PB 1 & 192 & 117 & 0.61 & 1 & WS 15 & 192 & 187 & 0.97 & 1 \\
\hline PB 2 & 192 & 121 & 0.63 & 1 & WS 16 & 192 & 115 & 0.60 & 1 \\
\hline PB 3 & 192 & 181 & 0.94 & 1 & WS 17 & 192 & 131 & 0.68 & 1 \\
\hline PB 4 & 192 & 103 & 0.54 & 1 & WS 18 & 192 & 168 & 0.88 & 1 \\
\hline PB 5 & 192 & 129 & 0.67 & 1 & WS 19 & 192 & 182 & 0.95 & 1 \\
\hline PB 6 & 192 & 132 & 0.69 & 1 & WS 20 & 192 & 164 & 0.85 & 1 \\
\hline PB 7 & 192 & 176 & 0.92 & 1 & WS 21 & 192 & 91 & 0.47 & 1 \\
\hline PB 8 & 192 & 174 & 0.91 & 1 & WS 22 & 192 & 165 & 0.86 & 1 \\
\hline PB 9 & 192 & 51 & 0.27 & 1 & WS 23 & 192 & 192 & 1.00 & 1 \\
\hline T & 192 & 142 & 0.74 & 1 & WS 24 & 192 & 192 & 1.00 & 1 \\
\hline WS 1 & 192 & 160 & 0.83 & 1 & WS 25 & 192 & 192 & 1.00 & 1 \\
\hline WS 2 & 192 & 176 & 0.92 & 1 & WS 26 & 192 & 192 & 1.00 & 1 \\
\hline WS 3 & 192 & 162 & 0.84 & 1 & Visual & 192 & 148 & 0.77 & 1 \\
\hline WS 4 & 192 & 149 & 0.78 & 1 & G & 192 & 184 & 0.96 & 1 \\
\hline WS 5 & 192 & 188 & 0.98 & 1 & CT & 192 & 184 & 0.96 & 2 \\
\hline WS 6 & 192 & 147 & 0.77 & 1 & ET & 192 & 141 & 0.73 & 2 \\
\hline WS 7 & 192 & 192 & 1.00 & 1 & Mon 1 & 192 & 192 & 1.00 & 1 \\
\hline WS 8 & 192 & 182 & 0.95 & 1 & Mon 2 & 192 & 183 & 0.95 & 1 \\
\hline WS 9 & 192 & 174 & 0.91 & 1 & PCK & 192 & 192 & 1.00 & 1 \\
\hline WS 10 & 192 & 170 & 0.89 & 1 & & & & & \\
\hline
\end{tabular}

The definition of the required number of work stations is performed based on the budget load. In table 4 are given the cycle time for all work stations. The measured results show that the cycle time is the same or significantly less than defined work takt.

For the analysis is taken the real number of stations, but the results of estimated budget and measured cycle time clearly show that certain stations are under the average work load.

Taken from the data in table 4.where are provided time for performing operations, it is possible to calculate the number of operators needed for every given group.

In table 5 is given a scheme of number of people in the system and number of people needed based on budget. According to this results, it is shown that in one manufacturing line is needed 7 operators less that the real state in system. Based on this, a new schedule is projected with its work stations and its appurtenant operations. (figure 6)

Here, the question of designing the system, if and how to reorganize it, is raised, without opardazing the efficiency.

Through analysis, a conclusion has been reached, that load of work station is not balanced and that the number of stations is greater that it should be based on the budget. This creates a place for further analysis in direction of balancing work stations and in determination of allowed deviation in operations (standard deviation). From the analysis, the present system is necessary to reorganize, to decrease the number of work stations and in accordance with all of this, organize and redeploy work operations.

Table 5. A scheme of number of people in the system and number of people needed based on budget

\begin{tabular}{|c|c|c|c|c|c|}
\hline Group operation & Takt & Cycle time & Load & $\begin{array}{l}\text { Needed number } \\
\text { of stations }\end{array}$ & $\begin{array}{c}\text { Number of stations } \\
\text { in system }\end{array}$ \\
\hline Preassembly & \multirow{8}{*}{192} & 538 & 2.80 & 3 & 4 \\
\hline Positioning & & 3026 & 15.76 & 16 & 20 \\
\hline The Installation of insulation & & 2058 & 10.72 & 11 & 13 \\
\hline The Installation of clip & & 576 & 3.00 & 3 & 3 \\
\hline The installations of grommet & & 184 & 0.96 & 1 & 1 \\
\hline Test & & 325 & 1.69 & 2 & 2 \\
\hline Final assembly & & 375 & 1.95 & 2 & 2 \\
\hline Packaging & & 192 & 1.00 & 1 & 1 \\
\hline & & & Total: & 39 & 46 \\
\hline
\end{tabular}




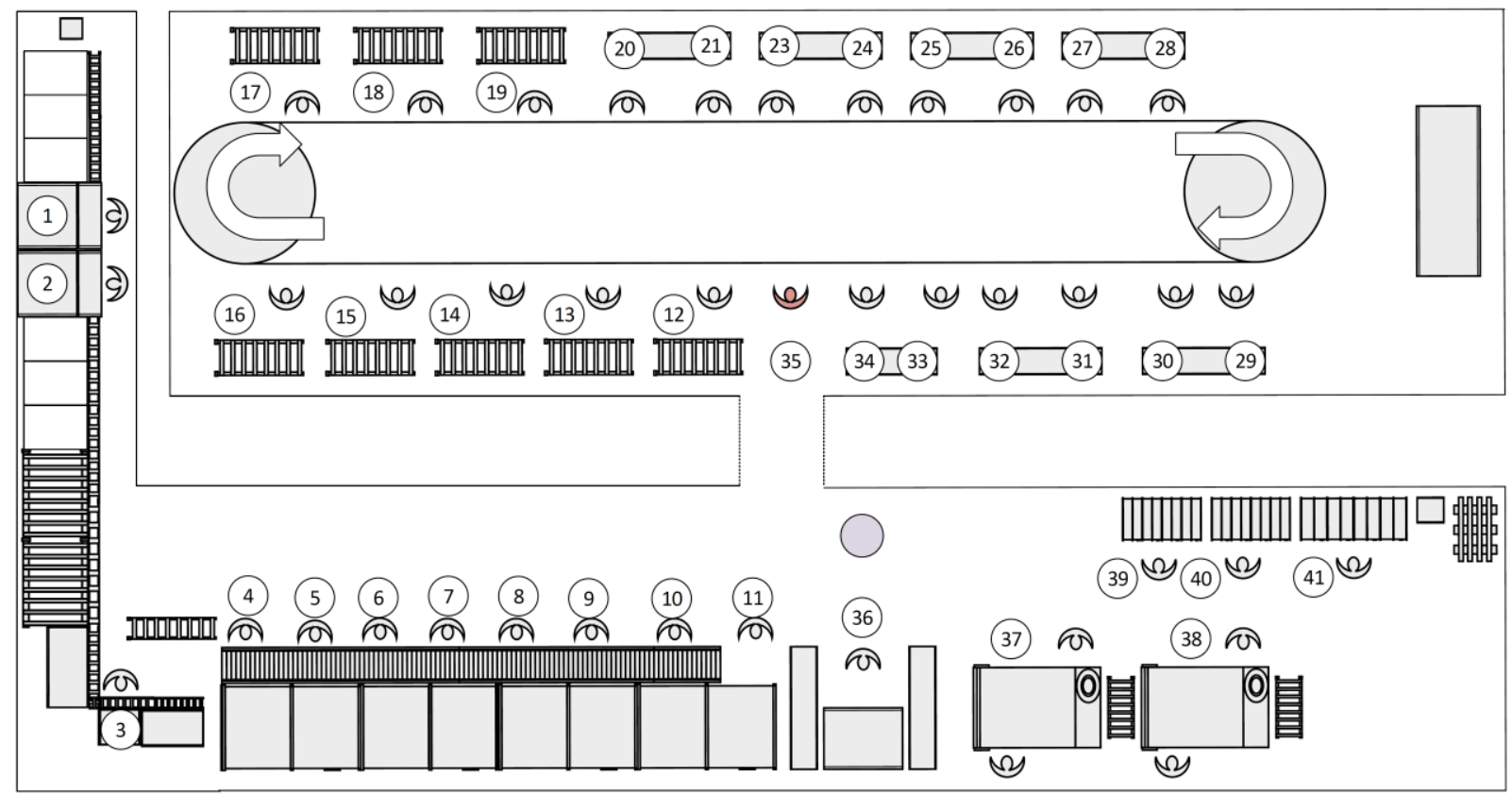

Figure 6. A layout of work stations with its operations after improvements

1,2 Work station - Ultrasonic welding; 3 work station - plugging; 4-19 work station - Positioning ; 20-31 work station - Banding; $32-34$ work station - the installation of clip; 35 work station - Visual control; 36 work station grommet; 37,38 work station - testing; 39,40 work station - final assembly ( the installation of canals). 41 work station - Packaging.

\section{CONCLUSION}

During the design of new or the optimization of existing assembly system, it is important to provide systematically approach to problem solving. Only the clear defined value can give a baseline for growth and advancement of the system.

The analysis, the designing and optimization of the element within the system, they demand the use of adequate instruments of Lean concept. Every step of the system designing and optimization relies on a set of appropriate elements of Lean. Regardless of the designing phase or optimization of the system, it is important to always focus on the value. This approach results in creating the elements that among all add to the value and not just simple competition of certain function.

By implementation of suggested system for assembly, it is confirmed that it is possible to optimize and balance cycle time in the system by eliminating NVA activities from operations. It is important that the focus must be on this, in the initial phases, as well as issue the processes so that NVA does not occur.

The directions of future researches will be focused on:

- the development of the general model for assembly system, based on Lean concept, which would have universal use,

- implementation of method and technique of artificial intelligence in assembly system,

- systematization of work operations and cycle time that will define wide spectrum of influencing factors, which in the initial phase must be considered and perceived.

\section{ACKNOWLEDGMENT}

This research has been supported by the Ministry of Education, Science and Technological Development, Government of the Republic of Serbia through the project TR35001-"Automated systems for identification and tracking of objects in industrial and non-industrial systems".

\section{REFERENCES}

[1] Gupta, S. and Kumar Jain, S. (2013), "A literature review of lean manufacturing", International Journal of Management Science and Engineering Management, Vol. 8, No. 4, pp. 241-249.

[2] Vukelic, D., Ostojic, G., Stankovski, S., Lazarevic, M., Tadic, B., Hodolic, J. and Simeunovic, N. (2011), "Machining fixture assembly/disassembly in RFID environment", Assembly Automation, Vol. 31, No 1, pp. 62-68.

[3] Bellisario, A. and Pavlov, A. (2018), "Performance management practices in lean manufacturing organizations: a systematic review of research evidence", Production Planning \& Control, Vol. 29, No. 5, pp. 367-385.

[4] Ostojic, G., Tadic, B., Luzanin, O., Stankovski, S., Vukelic, D., Budak, I. and Miladinovic, L. (2011), "An integral system for automated cutting tool selection", Scientific Research and Essays, Vol. 6, No. 15, pp. 3240-3251.

[5] Dattatray, A.A. and Kavade, M.V. (2018), "A Review of Assembly Line Changes for Lean Manufacturing", Journal of Mechanical and Civil Engineering, Vol. 1, No. 1, pp. 1-5.

[6] Bhamu, J. and Sangwan, K.S. (2014) "Lean manufacturing: literature review and research issues", International Journal of Operations \& Production Management, Vol. 34, No. 7, pp.876940.

[7] Ostojic, G., Stankovski, S., Vukelic, D., Lazarevic, M., Hodolic, J., Tadic, B. and Odri, S. (2011), "Implementation of automatic identification technology in a process of fixture assembly/disassembly", Strojniski vestnik - Journal of Mechanical Engineering, Vol. 57, No. 11, pp. 819-825.

[8] Maksimovic, R., Stankovski, S., Ostojic, G., Petrovic, S. and Ratkovic, Z. (2010), "Complexity and flexibility of production 
[9] structures", Journal of Scientific and Industrial Research, Vol. 69, No. 2, pp 101-105.

[10] Ostojic, G., Lazarevic, M., Stankovski, S., Cosic, I., and Radosavljavic, Z. (2008), "Radio frequency identification technology application in disassembly systems", Strojniski Vestnik/Journal of Mechanical Engineering, Vol. 54, No. 11, pp. 759-767.

[11] Alvarez, R., Calvo, R., Pena, M.M., Domingo, R. (2009), "Redesigning an assembly line through lean manufacturing tools", International Journal of Advanced Manufacturing Technology, Vol. 43, No. 9-10, pp. 949-958.

[12] Johnson, A., Balve, P. and Nagarur, N. (2012), "An investigation of internal logistics of a lean bus assembly system via simulation: A case study", International Journal of Industria Engineering: Theory Applications and Practice, Vol. 19, No. 1, pp. 14-25.

[13] Yi, T.P., Feng, C.J., Prakash, J. and Ping, L.W. (2012), "Reducing electronic component losses in lean electronics assembly with Six Sigma approach", International Journal of Lean Six Sigma, Vol. 3, No. 3, pp. 206-230.

[14] Sun, M., Zhang, X. (2012), "Assembly process application of lean quality management", Advanced Materials Research, Vol. 347-353, pp. 225-227.

[15] Arunagiri, P. and Gnanavel Babu, A. (2013), "Implementation of lean manufacturing system in bogie assembly in railway coach factory", Applied Mechanics and Materials, Vol. 248, pp. 511515.

[16] Yue, L. (2013), "Improvement and research of lean production in car-seat assembly line", Advanced Materials Research, Vol. 601 pp. 415-419.

[17] Balaji Paramesh, S.M. (2013), "Lean Six sigma Implementation in Cable Harness Manufacturing", International Journal of Mechanical and Production Engineering, Vol. 1, No. 1, pp. 4956.

[18] Zhang, Y., He, Z., Chen, T. and Zhang, M. (2013), "Assembly process improvement in company S: A lean six sigma case study", Advanced Materials Research, Vol. 655-657, pp. 2371 2374 .

[19] Wan Saidin, W.A.N., Aliaa Mohd Adnan, N., Kasim, N.I., Ibrahim, A.M. and Mujahid Ahmad Zaidi, A. (2014), "Realizing lean concept in automotive parts production: Child parts in subassembly line", Applied Mechanics and Materials, 660, pp. 10151019.
[20] Raghavan, V.A., Yoon, S. and Srihari, K. (2014), "Lean transformation in a high mix low volume electronics assembly environment", International Journal of Lean Six Sigma, Vol. 5, No. 4, pp. 342-360.

[21] Kanaganayagam, K., Muthuswamy, S. and Damodaran, P. (2015), "Lean methodologies to improve assembly line efficiency: An industrial application", International Journal of Industrial and Systems Engineering, Vol. 20, No. 1, pp. 104-116.

[22] Lam, N.T., Toi, L.M., Tuyen, V.T.T. and Hien, D.N. (2016), "Lean Line Balancing for an Electronics Assembly Line“, Procedia CIRP, Vol. 40, pp. 437-442

[23] Nguyen, M.N. and Do, N.H. (2016), "Re-engineering Assembly Line with Lean Techniques", Procedia CIRP, Vol. 40, pp. 591596.

[24] Mittal, K.K. and Verma, V. (2016), "Lean manufacturing system for air cleaner assembly cell", International Journal of Logistics Systems and Management, Vol. 23, No. 3, pp. 314-328.

[25] Usta, S.K., Oksuz, M.K. and Durmusoglu, M.B. (2017), "Design methodology for a hybrid part feeding system in lean-based assembly lines", Assembly Automation, Vol. 37, No. 1, pp. 84102.

[26] Rane, A.B., Sunnapwar, V.K., Chari, N.R., Sharma, M.R. and Jorapur, V.S. (2017), "Improving performance of lock assembly line using lean and simulation approach", International Journal of Business Performance Management, Vol. 18, No. 1, pp. 101124

[27] Devi, K.S., Arunachalam, V.P. and Gunasekaran, N. (2018), "Lean manufacturing concepts in wet grinder assembly line through value state mapping", International Journal of Services and Operations Management, Vol. 30, No. 3, pp. 357-370.

[28] Botti, L., Mora, C. and Regattieri, A. (2017), "Integrating ergonomics and lean manufacturing principles in a hybrid assembly line", Computers and Industrial Engineering, Vol. 111, pp. 481-491.

[29] Debevec, M., Pipan, M., Zupan, H., Herakovic, N. (2016), "An innovative training of production planners through virtual production performing", Tehnički vjesnik, Vol. 23, pp. 363-369., ISSN 1330-3651 (Print), ISSN 1848-6339 (Online), DOI: $10.17559 /$ TV-20150130124330

\title{
Optimizacija sistema kablovskih sklopova zasnovanih na primeni Lean koncepta
}

\author{
Nataša Klašnja, Nemanja Sremčev, Djordje Vukelić, Nenad Simeunović, \\ Milovan Lazarević
}

Primljen (15.07.2018.); Recenziran (23.09.2018.); Prihvaćen (27.09.2018.)

\begin{abstract}
Abstrakt
U ovom radu je izvršena analiza proizvodnog sistema za montažu kablovskih snopova od trenutka montaže sa fokusom na gubitke u radnom procesu. Napravljen je predlog prema metodologiji za unapređenje u montažnom sistemu zasnovanom na Lean konceptu. Na osnovu predložene metodologije izvršena je optimizacija broja radnih stanica. Dobijeni rezultati ukazuju na to da je moguća efikasna implementacija Lean koncepta u procesu montaže kablovskog snopa. Na kraju se daju odgovarajući zaključci i pravci budućih istraživanja.
\end{abstract}

Ključne reči montaža, lean, kablovski snop 